\title{
The Effectiveness of Bibliotherapy to Decrease Negative Thoughts Towards Children with Special Need
}

\author{
A. Khusumadewi \& E. Sholeha ${ }^{\mathrm{a}}$, I. Ifdil ${ }^{\mathrm{b}}$ \\ ${ }^{a}$ Universitas Negeri Surabaya, Surabaya, Indonesia \\ ${ }^{\mathrm{b}}$ Universitas Negeri Padang, Padang, Indonesia
}

\begin{abstract}
The aim of this research is to test the effectiveness of bibliotherapy technique to decrease students' negative thoughts toward special need children. This research was conducted in an inclusion school where interactions between special need children and normal students are managed. One group pretest and post-test were assigned in advance. The instrument used in this research was questionnaires about negative thoughts towards special need children consisting of 22 items. The subjects of this research were 6 regular students of an inclusion school who were indicated as having high negative thoughts towards special need children. The data were analyzed through signedrank non-parametric statistic test of Wilcoxon to discover the difference of pre-test and post-test. The results of the data analysis showed that the pre-test average score was 32.83 , the post-test average score was 25.83, $\rho$ (the possibility of value was below $\mathrm{H}_{0}$ ) $=0.028$ and $\alpha$ (error degree $)=5 \%$ or 0.05 , therefore $0.028<0.05$. Thus, $\mathrm{H}_{0}$ was denied. Therefore, it could be concluded that bibliotherapy was effective in decreasing the negative thoughts of regular students in inclusion schools.
\end{abstract}

\section{Keywords-Bibliotherapy, Negative Thoughts}

\section{INTRODUCTION}

An inclusion school is one of the answers for children's equality of rights in receiving education. In Surabaya, it is the government's featured program to convert all junior and senior public schools to inclusion schools. A school is a building or an institution in which teaching and learning activities occur. In other words, it is a place where some particular people transfer and receive lessons. Inclusive is a term used to describe a way to integrate students with special needs into regular school programs [10]. Hence, it can be concluded that an inclusion school is an institution which provides the opportunity for students with special needs to learn with other normal students in the same boat.

In the implementation, there are several issues occur. They can be dealing with the curriculum, teaching and learning process, or students' improvements. A counseling program aims at assisting students to reach their optimal development. The issues appear because of the differences occurring between in- clusive and normal students that obstructed the social and personal development of the students. They tend to restrain themselves from mingling with the inclusive students, have negative thoughts about them, feel scared and insecured, and also give limitations in learning and making friends whenever it deals with inclusive students.

A different condition experienced by some students with special need in SMPN 4 Waru Sidoarjo in which they bring negative ideas to regular students because every person has automatic perceptions. Most of them actually had negative thoughts or perceptions toward others. It is because the automatic perceptions are cognitively dysfunctional system or distortion perceptions which are exaggerative and irrational [2].

This reasearch aimed at testing the effectiveness of bibliotherapy technique to decrease negative thoughts on students with special need. The research result showed that the technique was effective in decreasing the issues in students. It was shown by the score of the negative thoughts on special need children got smaller. Moreover, there were changes on behaviours of the subject research for the special need students.

The different thoughts towards students with special needs exists among the students of the inclusive school. Some of them thought that the students with special need have the same potentials as children in common. They, however, have sympathy for them although most of them carry negative thoughts towards students with special needs.

Rebellious, temperamental, and sometimes dangerous are the perceptions they have about students with special needs. They once watched movie scenes where there were children with special needs threw tantrum and attacked people around. Besides, they ever witnessed an Autism Spectrum Disorder (ASD) students bridled. From those experiences, they inferred that children with special need are rebellious, temperamental and dangerous.

Another negative perception about children with special need is that they are slow as what the regular students have en- 
countered. The special need children tend to learn and response slowly in conversations and tend to be passive in the teaching-learning process in the classroom. This point shows how such perception was built.

Besides, having seen some physically handicapped people (the blind, losing arms or legs, and becoming beggars) had made the regular students see the students with special needs as weak individuals. However, not all children with special need end up becoming beggars. It shows that there is confusion of perceptions towards the disabilities of the children with special need and the exaggerating views.

The negative thoughts can affect one's feelings and behaviors [1]. Several impacts of negative thoughts deal with apprehensive feeling, being afraid, disliking, accusing, calling names, and judging [8]. Based on the observation, it was discovered that those things had caused the regular students to stay away from the students with special need.

When the slow learning students approached the regular students who were chatting, they tended to evade them. They also refused to lend their stationeries when they sat next to the special need students for they were afraid that their belongings might be broken. One of the students in the classroom also easily lost his temper to the slow learning students without any clear reasons. Moreover, two regular students were caught of calling 'SNC' for Special Need Children to any classmates who are regular students but likely to bother others in the classroom. Those things were done out of the teacher's supervision.

If the negative thoughts were not eliminated, the regular students would keep feeling afraid and disliking them. With the regular students staying away from the special need students, they would feel that their presences were not appreciated and expected.

Negative thoughts are actually the result of subjective automatic perception which is based on one's past experiences, knowledge, acquired values, and cultural background [9]. The negative thoughts, in this case, were caused by the regular students' lack of knowledge of the different conditions happening to special need children. Through bibliotherapy, they are to draw more information about it. Then, they are going to improve their behaviors, mindsets, and perceptions as well as change the social stigma and so on [11]. It is one of counseling techniques which makes use of written media in the process.

Bibliotherapy is an expressive therapy in which there is a connection between a person and the content of books and poetries or other writings used as a therapy [4]. It can be applied to an individual, group, or classical context [4]. Its practice is adapted to the student characters who have been accustomed to the school's literacy movement program. One of the activities is 15-minute reading of any non-school textbooks before the teaching and learning activities start. The goal of this program is to grow students' interests in reading as well as to improve their reading skill [6].

\section{METHOD}

This study was an experimental research and the design used was one group pre-test ad post-test. It involved the participation of a group of subjects, measures the results before and after the treatments in which the treatment score margin was seen as the effect of the treatments [7].

The subjects were the regular students of VII-7 at SMPN 4 Waru inclusion school who were identified for having highly categorized negative thoughts on special need students based on the pilot study using questionnaires about special need children.

The research instruments used in this research were questionnaires of negative thoughts towards special need children consisted of 22 items of statements with 4 multiple-choice optional answers: strongly agree, agree, disagree, and strongly disagree.

The data analysis used was non-parametrical statistic of Wilcoxon-signed ranking test to remark the score margin before and after the treatments.

\section{RESULTS AND DISCUSSION}

There were six subjects in this research. They have highly categorized negative thoughts towards children with special need.

The treatment given was bibliotherapy technique applied in a counseling group for five meetings. The first meeting was used for bonding the counselor and the counselee. A general overview of the planned activities was given and a commitment to join them was made. The second meeting was used to identify the negative assumptions that each counselee had towards special need children and the factors beyond the negative thoughts. The third and fourth meetings were used to give new knowledge related to the conditions of special need children and the strengths they have. The fifth meeting was used to find out the improvement of the counselees' mindset, feelings, and attitudes after several meetings of the therapy.

A post-test was conducted to measure the score of negative thoughts on special need children after treatments were given. The table below shows the data of the pre-test and post-test scores:

TABLE I. DATA OF THE PRE-TEST AND POST-TEST SCORES

\begin{tabular}{|l|l|l|l|}
\hline \multicolumn{1}{|c|}{ Name } & $\begin{array}{c}\text { Pre-test } \\
\text { scores }\end{array}$ & \multicolumn{1}{c|}{$\begin{array}{c}\text { Post-Test } \\
\text { scores }\end{array}$} & $\begin{array}{c}\text { Changing of } \\
\text { Scores }\end{array}$ \\
\hline AOR & 32 & 23 & -9 \\
\hline EDCR & 31 & 29 & -2 \\
\hline LF & 34 & 26 & -8 \\
\hline LLA & 32 & 26 & -6 \\
\hline SDF & 37 & 24 & -13 \\
\hline SPA & 31 & 27 & -4 \\
\hline
\end{tabular}


To see the effectiveness of the bibliotherapy technique in decreasing negative thoughts on special need children, we analyzed the result of the pre-test and post-test through statistical checking using Wilcoxon-signed ranking test. In addition, SPSS 16.0 for Windows 7 was employed in order to get the result as shown in the table below:

TABLE II. DATA RESULT USING WILCOXON-SIGNED RANKING TEST

\begin{tabular}{|l|l|}
\hline & \multicolumn{1}{|c|}{ Postest-Pretest } \\
\hline Z & $-2.201^{\mathrm{a}}$ \\
Asymp. Sig. (2-tailed) & .028 \\
\hline
\end{tabular}

Based on the data analysis of non-parametrical statistic with Wilcoxon-signed ranking test, it was obtained that $\rho$ (the possibility of value below $\mathrm{H}_{\mathrm{o}}$ ) $=0.028$ and $\alpha$ (degree of error) $=5 \%$ or 0.05 , therefore $0.028<0.05$.

This research was a pre-experimental research and the research design involved one group of pre-test and post-test which means that there was only one group of subjects given treatment without the existence of any control group as a comparison.

In this research, bibliotherapy technique could significantly decrease the negative thoughts of the regular students of grade VII towards children with special need. The negative thoughts were caused by their lack of knowledge about the conditions of special need children and inconvenient experiences when they saw and had interactions that kind of children.

The bibliotherapy conducted in this research was considered as humanistic education. In this type, bibliotherapy may broaden one's point of view about different conditions of human beings [3]. Through bibliotherapy, the research subjects learnt that the bad behaviors showed by the special need children was due to their divergence.

The new knowledge shaped a new mindset that the conditions of the special need children which had made them behaved in such ways. It could be seen here that the bibliotherapy could stimulate teenagers to think easily [5]. Therefore, the negative thoughts towards special need children tended to decrease after the application of bibliotherapy.

The decrease of the negative thoughts also affected their changing of feeling and attitudes. Students who previously felt afraid, dislike, and stay away from special need children turned out to be more caring and willing to start interactions with them. It was because bibliotherapy is a technique which may bring changing of feelings and attitude (Tanrikulu, 2011; Karacn \& Yerin-Guneri, 2010; Yilmaz, 2002). From this research, the improvements that could be seen is that the regular students started to sosialize with students with special needs as the negative thoughts within them had decreased.
The pre-test showed that the six students had high negative thoughts towards special need students. Then, they were given bibliotherapy technique in group counseling. After the therapy, a post-test was conducted to them.

By using the data taken from the pre-test and post-test, the data analysis applied was non-parametric Wilcoxon-signed ranking test. The result was $\rho$ (the possibility for value is below $\left.\mathrm{H}_{\mathrm{o}}\right)=0.028$ and $\alpha$ (degree of error) $=5 \%$ or 0.05 , therefore $0.028<0.05$. Thus, $\mathrm{H}_{\mathrm{o}}$ was denied. For that reason, it could be concluded that bibliotherapy technique was effective in decreasing the negative thoughts of regular students inclusion school.

This research can be used as a reference for next researches and may be developed by other researchers dealing with bibliotherapy technique or negative thoughts towards special need children. However, during the research, there were several things that must be controlled as they might interfere the research result, such as cultural background, knowledge on special need children, and time management of the implementation.

For the next researches, the time and number of meeting and the kinds of literatures for the therapy should be considered. The research subjects should also be increased. Through that way, hopefully a more maximum research result can be obtained.

\section{CONCLUSIONS}

Bibliotherapy is effective in reducing negative thoughts on children with special needs. This is supported by the research result that brought changes in the regular students' behavior. In addition, in employing bibliotherapy, the characteristics of the subject is an important aspect to concern with. It is also suggested that those who employ bibliotherapy use materials that are adapted to the real condition of subject's negative thoughts. Furthermore, the research subjects should be the students who have been familiar with reading and reviewing activity.

\section{REFERENCES}

[1] D. Ainy, Terapi Kognitif. (Online) (http://daraainy.blogspot.co.id/2012/09/terapi-kognitif.html, 21st January 2017), 2012.

[2] A.T. Beck, Cognitive Therapy and The Emotional Disorders, New York: International Universities Press, 1976.

[3] L.M. Brammer and G. MacDonald, The Helping Relationship Process and Skills. Boston: Allyn and Bacon, 1996.

[4] E.E. Eliasa, Bibliotherapy As A Method of Meaningful Treatment, Yogyakarta: Universitas Negeri Yogyakarta, 2011.

[5] E.E. Eliasa and S. Iswanti, Bibliotherapy With The Career Topic To Increase The Student's Career Motivation Of Guidance And Counseling. Procedia - Social and Behavioral Sciences volume 114: 434-438, 2013.

[6] Kemendikbud, Buku Saku Gerakan Literasi Sekolah: Menumbuhkan Budaya Literasi di Sekolah, Jakarta: Satgas Gerakan Literasi Sekolah, 2015 . 
[7] Latipun, Psikologi Eksperimen. Malang: Penerbitan Universitas Muhammadiyah Malang, 2006.

[8] D.A. Mutiara, Apakah Anda Penderita OCD. (Online).(http://wartakota.tribunnews.com/2013/05/23/apakah-andatermasuk-penderita-ocd, 21st January 2017), 2013.

[9] Sapon, Sri Ramadhani. Terapi Kognitif. (Online). (http://studentners.blogspot.co.id/2013/11/terapi-kognitif.html, 21st January 2017). 2013.

[10] J. D. Smith, Sekolah Inklusif: Konsep dan Penerapan Pembelajaran Cetakan 3. Terjemahan Denis Enrica, Bandung: Penerbit Nuansa Cendikia, 2012.

[11] A. Solikin, Biblioterapi Sebagai Sebuah Teknik dalam Layanan $\begin{array}{lll}\text { Bimbingan Konseling. (Online). } & \end{array}$ (http://www.umpalangkaraya.ac.id/dosen/asepsolikin/?p=143, 10 th January 2017), 2015.

[12] I. Tanrikulu, Self Helps Book And Bibliotherapy: [13] Reflections for Turkey. Procedia - Social and Behavioral Sciences volume 30: 1862-1866, 2011. 